\title{
İş Stresinin Örgüt İçi Çatışmaya Etkisi: Sivil Havacılık Çalışanları Üzerine Bir Araştırma
}

\section{The Effect of Work Stress on Organizational Conflict: A Study on Civil Aviation Workers}

\author{
İnan Kaynak ${ }^{a, *}$
}

${ }^{a}$ Öğr. Gör. Muş Alparslan Üniversitesi, Malazgirt Meslek Yüksekokulu, Finans Bankacılık ve Sigortacılık Bölümü, Muş/Türkiye. ORCID: 0000-0001-9944-1540

\section{MAKALE BILGIISI \\ Makale Geçmişi: \\ Başvuru tarihi: 2 Aralık 2020 \\ Düzeltme tarihi: 11 Şubat 2021 \\ Kabul tarihi: 23 Şubat 2021}

\section{Anahtar Kelimeler:}

Stres

İş Stresi

Çatışma

Örgütsel Çatışma

Sivil Havacilık

\section{A R T I C LEINFO}

\section{Article history:}

Received: December 2, 2020

Received in revised form: February 11, 2021

Accepted: February 23, 2021

\section{Keywords:}

Stress

Work Stress

Conflict

Organizational Conflict

Civil AviatioN
ÖZ

$\mathrm{Bu}$ araştırma iş yerindeki stresin çatışmaya olan etkisini ölçmek için yapılmıştır. Araştırma için 2 boyut ve 8 maddeden oluşan çatışma ölçeği ile iki boyut ve 9 maddeden oluşan iş stresi ölçeği kullanılmıştır. Bu kapsamda İstanbul Hava Limanında görevli yolcu hizmetleri memurları ile anket çalışması yapılmıştır. 416 kişiden alınan cevaplarla veri seti oluşturulmuştur ve veriler SPSS 25.0 programında analiz edilmiştir. Çalışma sonuçlarına göre, iş stresinin alt boyutlarından zaman stresinin görev çatışmasını etkilediği fakat ilişki çatışmasını etkilemediği anlaşılmıştır. Yine iş stresinin alt boyutlarında zaman stresi ve iş kaygısının, çatışmanın alt boyutları olan görev ve ilişki çatışmasını pozitif yönde etkilediği sonucuna varılmıştır. Çalışma neticesinde ulaştı̆̆ımız sonuçlar, literatürle uyumlu bir şekilde stresin çatışmayı etkilediğini ortaya koymuştur.

\section{A B S T R AC T}

This research was conducted to measure the impact of stress in the workplace on conflict. For the research, the conflict scale consisting of 2 dimensions and 8 items and the work stress scale consisting of two dimensions and 9 items were used. Within this scope, a survey was conducted with the passenger services officers employed at Istanbul Airport. A data set was created with the answers received from 416 people and the data were analyzed in the SPSS 25.0 program. According to the results of the study, it was understood that time stress, which is one of the subdimensions of work stress, affects task conflict but not relationship conflict. It was concluded that time stress and work anxiety positively affect task and relationship conflict, which are subdimensions of conflict, in sub-dimensions of work stress. The results we obtained as a result of the study revealed that stress affects conflict in accordance with the literature.

\section{Giriş}

Çalışanların zamanlarının önemli bir kısmını harcadıkları iş yaşamındaki bazı gelişmeler, örgütsel ilişkilerde olumsuz sonuçlar doğurabilmektedir (Asunakutlu ve Safran, 2006). Günlük hayatta sıkça kullanılan kavramlardan biri olan stres bu sorunlardan birisidir (Uludağ, 2019). İş ortamı stres oluşumuna elverişli yerlerdir (Karakuş, 2019) ve yoğun iş temposu önemli bir stres kaynağ 1 durumuna gelmiştir (Turunç ve Erkuş, 2010).

\footnotetext{
*Sorumlu yazar/Corresponding author.

e-posta: i.kaynak@alparslan.edu.tr
}

Tüm iş yaşamında stres yaygın olarak yaşanmakla birlikte bazı meslek türleri yüksek stresi doğasında barındırmaktadır (Özmutaf ve Mizrahi, 2017). Diğer sektörle kıyaslandığında sivil havayolu taşımacılığı nispeten daha stresli bir ortama sahiptir (Çiçek, 2020). Birçok stres kaynağının olduğu çalışma ortamında (Aktaş, 2001) stresin uzun sürmesi ve çalışanın stres karşısında yetersiz oluşu, çalışanların çatışmaya girmesini kolaylaşmaktadır (Özmutaf, 2007).

Birçok bilim dalı ve özellikle de yönetim biliminin çalışma konusu olan çatışma kavramı (Topaloğlu ve Boylu, 2006), 
iki farklı taraf arasındaki pozisyon, tutum ve davranışlarda algılanan farklılıklar olarak açıklanabilir (Çiçek ve Almalı, 2020). Toplumsal bir olgu olan çatışma örgütsel yaşamın da gerçeklerindendir (Karcıoğlu ve Alioğulları, 2012).

Örgütler günümüz dinamik iş koşullarından dolayı farklı kültürlerden gelen çalışanlardan oluşmaktadır. Örgütün amaçları genel anlamda çalışanların amaçları olsa da bazı örgütsel ya da bireysel nedenlerden dolayı çatışmalar yaşanabilmektedir (Akkirman, 1998). Çatışma modern örgütlerin önemli sorunlarından biridir. Çatışmaların düzeyi ve sıklığg iş görenlerin örgütsel bağlılığını, örgütsel sapma davranışını, iş doyumunu, çalışma yaşam kalitesini ve en önemlilerinden biri olan verimliliğini etkilemektedir (Demir, 2010).

Çatışma kavramı ile ilgili görüşlerden klasik görüşe göre çatışmalar örgütler için zararlıdır ve ortaya çıktığı andan itibaren yok edilmeye çalışılmalıdır. Modern görüşe göre ise çatışma kaçınılmazdır ve belirli düzeyde olması örgüte çeşitli faydalar sağlayabilir (Yelkikalan, 2006). Hayatın her alanında olan örgütlerde (Kaynak, 2020) çatışmaların olması kaçınılmaz ise çatışmanın neden olduğu olumsuzluklar giderilerek örgüt yararına etkili bir şekilde kullanılması gerekmektedir (Özdemir, 2018).

$\mathrm{Bu}$ çalışmada stres ve iş stresi kavramlarıyla birlikte çatışma ve örgütsel çatışma kavramları incelenmiştir. İş stresinin alt boyutları zaman stresi ve iş kaygısının örgütsel çatışmanın alt boyutları olan görev çatışması ve ilişki çatışmasına olan etkisi araştırılmıştır. Literatür incelemesi yapıldığında stresle ve çatışma ile ilgili birçok çalışma olduğu fakat stresin çatışmaya olan etkisini inceleyen araştırmaların azlığı nedeniyle literatüre katkı yapacağ düşünülmektedir.

\section{Araştırma İle İlgili Kavramlar}

\section{1. İş Stresi}

Stres modern yaşam hastalığı olarak tanımlanmakla birlikte (Büyükaslan ve Eriş, 2019) sabahları hasta hissetmekten endişeye yol açan her şey, hatta depresyona kadar çeşitli şekillerde kullanılmaktadır (ILO, 2016). Günlük hayatımızın bir parçası durumuna gelmiş stres yeni bir kavram değildir (Torun ve Tekin, 2014). Eski devirlerden beri bilinen stres (Çınar, 2010), Latince "estrictia" sözcüğünden gelmektedir. 17. yüzyılda keder, dert, elem, musibet, bela, felaket anlamlarında kullanılırken, 19. yüzyılda ise zor ve baskı gibi ruhsal yapılara dönük anlamlar olarak kullanılmıştır (Güçlü, 2001). Stresle ilgili ilk çalışmaları yapan Selye bu kavramı "vücudun herhangi bir dlş talebe verdiği özel olmayan tepki” olarak tanımlamıştır (Turunç ve Çelik, 2010).

Kişiler üzerinde psikolojik etkileri olan ve günlük yaşamda davranışları, ilişkileri ve verimliliği etkileyen stres (Yıldız ve Bayrakç1, 2020), bir sağlık sorunu değil fakat zararlı fiziksel ve duygusal bir durumun ilk işaretidir (ILO, 2016). Soyut bir kavram gibi algılanan stres sebep olabileceği muhtemel olumsuzluklarından dolayı başa çıkılması gereken bir konudur (Ergün ve Yüksel, 2019). Hayatın tüm alanlarında ortaya çıkabilen, kimi zaman bireye güç katarken kimi zamanda yapabileceği şeylere engel olabilen (Yetim ve Çevik, 2019), yalnızca ruh ve beden sağlığını değil çalışma performansını da etkileyen (Yaşartürk ve
Yılmaz, 2019), belli bir düzeye kadar performansı arttırıp bu seviyeden sonra ise performansı düşürücü etkileri olan bir kavramdır (Çelik ve Turunç, 2009). Toplumdaki her bireyin çeşitli sebeplerle yaşadığ 1 stres, hem kendisi hem de çevresi üzerinde olumsuz etkilere neden olabilmektedir (Kaya, 2010). Bu bağlamda sadece iş görenleri etkileyen bir sorun olmayıp (Çelik ve Turunç, 2009) örgütlere de bazı ekonomik zorluklar yaşatan bir konudur (Bayarçelik, Durmaz ve Gürler, 2019).

Sanayi Devrimi sonrasında yaşamlarının önemli bir kısmını geçirdikleri çalışma ortamı, fiziksel ve özellikle de zihinsel olarak insanları etkilemiştir (Doğan ve Oğuzhan, 2020). İş hayatı bazı etmenlerden dolayı iş görenlerin en fazla strese maruz kaldığı ortamdır (Uludağ, 2019). Çalışanların iş ortamında maruz kaldıkları işle ilgili strese "iş stresi" denilmektedir (Köse, 2020). İş stresi literatürde meslek stresi veya örgütsel stres olarak da adlandırılmaktadır (Adıgüzel, 2012). İş stresi kavramı en genel ifadeyle şöyle tanımlanabilir: Belirli bir iş ortamında uyarıcılara karşı verilen tepki olarak ortaya çıkan (Büyükyılmaz, Karakulle ve Karataş, 2018), iş yerinde bireysel veya örgütsel farklılıklardan kaynaklanan (Adıgüzel, 2012), örgütsel kaynak veya ihtiyaçlarda uyuşma olmadığında yaşanan (Yetim ve Çevik, 2019), çalışanların fiziksel veya psikolojik davranışlarını değiştiren (Yaşartürk ve Yılmaz, 2019), bireyler ve örgütler için zararlı sonuçları olabilen (Kaya, Güzel ve Çubukçu, 2011) ve hatta verimlilik düşüşü nedeniyle örgütlere ekonomik zorluklar yaşatabilen (Bayarçelik vd., 2019), kişilerin iç dünyasında yaşadığı ( Yıldız ve Şimşek, 2020) psikolojik bir durumdur (Yaşartürk ve Yilmaz, 2019).

Örgüt içi ve örgüt dışı birçok faktör çalışanları etkileyebilmektedir. İş stresi bu faktörlerin en önemli olanlarından biridir (Atan ve Tekingündüz, 2014). İş stresi son zamanlarda en çok ilgi çeken ve incelenen konulardan biri haline gelmiştir. Bu sebeple kavramın etkilerini ve sonuçlarını incelemek hem kamusal hem de özel tüm sektörlere bağlı örgütlerde rağbet görmektedir (Akçakanat, 2019).

İş stresi örgütün içinden veya dışından, gruplardan veya çalışanlardan kaynaklı olarak çeşitli nedenlerle ortaya çıkabilir (Torun ve Tekin, 2014). Stres kaynakları ile ilgili sınıflandırmada örgüt yapısı ve politikalarının yanı sıra sosyal hayat, bireysel kaynaklar ve dış çevre kaynaklarına yer verilmektedir (Aktekin, Özmutaf ve Ergani, 2018). Örgütler büyüyüp karmaşıklaştıkça iş görenleri etkileyen stres faktörleri artmakta ve hatta belirsizleşmektedir (Aktaş, 2001). İş stresine sebep olan faktörler farklılaşmakla birlikte iş stresin başlıca kaynakları işle ilgili sebepler, örgüt içi roller, kariyer beklentileri ile ilgili nedenler, örgütün yapısı ve iklimi olabilmektedir. İşyerinden kaynaklı stres faktörleri, nevrotik kişilik, kaygı düzeyi, belirsizliğe karşı düşük tolerans gibi bazı bireysel kaynakları etkileyebilmektedir. Ayrıca finansal ve ailevi zorluklar gibi örgüt dışı kaynaklar birleştiğinde bireylerin stres düzeyleri zarar verici durumlara ulaşabilmektedir. Stres belirtileri bireyler arasında farklılaşmakla birlikte, genellikle kalp ritim bozukluğu, kolesterol ve tansiyon gibi fiziksel sonuçlardır. Bunlara ilaveten stres, aşırı sigara kullanımı, depresif ruh hali, isteksizlik ve iş memnuniyetsizliği biçimlerinde de kendini gösterebilmektedir (Çiçek, 2020). 
İş stresi bireyin özel hayatını ve iş yaşamını etkilemektedir (Yıldız ve Tekin, 2018). Fakat iş stresi sadece iş görenlerin baş etmek zorunda oldukları bir durum değildir, aksine örgütün iş stresine neden olan sebepleri belirleyerek ortadan kaldırması gerekir (Karakulle, Karademir ve Armağan, 2019). Çalışanların maruz kaldıkları stresin azaltılması, örgüt performansı ve verimliliği için yaşamsal öneme sahiptir (Doğan ve Oğuzhan, 2020). Çünkü stres, iş görenin verimliliği ile yakından ilgili bir kavram (Örücü ve Demir, 2010) olmakla beraber, performans davranışlarını doğrudan etkilemektedir (Onay ve Kılc1, 2011). İş stresi, iş görenin işe olan ilgisini azaltır. Performans düşüklüğü, işe devamsızlık, işten ayrılma niyetinde artış, işe yabancılaşma, aile ve sosyal yaşantıda sorunlar yaşama (Baltacı, 2018), iş disiplinin ve örgütsel yapının bozulması, çalışma arkadaşları arasında davranış bozukluğu, takım çalışmasında bozulma ve sonucunda da çalışanlar arasında çatışmalara neden olabilmektedir (Karakulle vd., 2019).

\section{2. Örgütsel Çatışma}

İnsan tüm üretim faaliyetlerinin amacı ve örgütsel hedeflerin temel kaynağıdır. Yaşadığı çevre ve toplumun etkisiyle kişilerin inanç sistemi, değerleri ve tutumları birbirinden ayrışmaktadır. $\mathrm{Bu}$ bireysel farklılıklar çatışmanın kaçınılmazlığını beraberinde getirir (Topaloğlu ve Boylu, 2006). Ayrıca insanın etkileşime ve iletişime açık bir şekilde hayatını devam ettirmesi, çatışma yaşamasını da kolaylaştırabilmektedir (Gürcüoğlu ve Uyar, 2020).

Çatışma kavramı çağrıştırdığı anlam itibariye mücadele, kavga, savaş gibi olumsuz bir durum içerir (Sarpkaya, 2002). Bu sebeple kavramı tanımlamak oldukça zordur. Çünkü çatışmalar farklı ortamlarda ve düzeylerde ortaya çıkmakta ve ortaya çıkış şekilleri de çok farklı olabilmektedir (Tokat, 1999). Koçel (2014)'e göre çatışma: "iki veya daha fazla kişi veya grup arasındaki çeşitli kaynaklardan doğan anlaşmazlık” olarak tanımlanmaktadır. Eren (2016)'e göre ise çatışma: "Bireylerin ve grupların birlikte çalışma sorunlarından kaynaklanan ve normal faaliyetlerin durmasina veya karışmasına neden olan olaylardır.",

Genel bir ifadeyle çatışma: İki ya da daha fazla kişi veya grubun tutum, değer veya davranışları sonucunda, tarafların çıkarlarını birbirinin tersi olarak algılaması (Birsel, İslamoğlu ve Börü, 2009), birinin kazancının öbürünün kaybı gibi görülmesinden kaynaklanan düşmanlık, kavga, huzursuzluk ve stres gibi olumsuz davranışlara sebep olan (Akkirman, 1998) ve taraflar arasında anlaşmazlığa yol açan sosyal bir olgu olarak tanımlanabilir (Özalp, 1989).

Toplumsal yaşamın önemli bir kısmını oluşturan örgütler, bünyelerinde farklı kişi ve gruplar barındırmaktadırlar (İmirlioğlu, 2005). $\mathrm{Bu}$ kişiler farklı kültürlerden gelmelerine rağmen amaçları örgütün hedeflerini gerçekleştirmektir (Akkirman, 1998). Örgütlerde bu etkileşim içinde olanların çatışma yaşaması örgütsel yaşamın bir gerçeğidir (Karcıŏlu ve Alioğulları, 2012). Örgütsel çatışma ise örgüt içindeki birey veya grupların kaynak ya da görev paylaşımı ile yine bu kişiler arasındaki alg1 farklılıkları, amaç, değer veya statü farkından kaynaklanan uyuşmazlık ya da anlaşmazlık olarak nitelendirilmektedir (Düşükcan, 2018). Örgütsel çatışmalar; tarafların niteliklerinden ve ilişkilerinden, çatışmaya sebep olan konudan ve sosyal çevreden, çatışma sırasında uygulanan taktik ve strateji ile sonuçlarından etkilenen ve geniş bir alana etki eden bir süreçtir (Sökmen ve Yazıcıoğlu, 2005).

Çatışma kavramı birçok bilim dalınca incelenmiş ve tartışılmıştır. Sanayi devrimi sonrası ise örgütsel anlamda ciddi manada bir araştırma konusu olmuş ve günümüze kadar ki süreçte birçok farklı görüş oluşmuştur (Şahin ve Çekmecelioğlu, 2016). Bu görüşler geleneksel(klasik), neoklasik ve modern görüşler olarak sıralanabilir (Sarpkaya, 2002). Klasik yaklaşımın savunucuları çatışmaların verimliliği azalttığını, örgütün normal işleyişini bozduğunu, örgütler için zararlı olduğunu ve her ne surette olursa olsun ortadan kaldırılması gerektiğini savunmuşlardır (Yelkikalan, 2006). Neo-klasik yaklaşım ise klasik yaklaşıma benzer şekilde çatışmaların örgüt için zararlı sonuçlar doğurduğunu ve ortaya çıkmasıyla birlikte ortadan kaldırmaya matuf önlemlerin alınması gerektiğini ileri sürmüştür (Ertürk, 1993). Neo klasik yaklaşım, klasik yaklaşımdan farklı olarak çatışmanın muhtemel olumlu yönlerinin tespit edilip ortaya çıkarılması gerektiğini savunmuştur (Göl, Arslankılıç ve Göl, 2017). Çağdaş yaklaşımlar ise çatışmaların kaçınılmaz olduğunu, insan var oldukça çatışmaların da olacağını ve bu gerçekten hareketle, çatışmaları bitirmek yerine yönetmeye ve olumsuz etkilerini örgüte yararlı hale dönüştürmeye gayret gösterilmesi gerektiğini savunmuşlardır (Gürcüoğlu ve Uyar, 2020). Doğru yönetilen çatışmaların çalışanların performansını arttırarak örgütün verimliliğini artırıcı bir işlev gördüğü bilinmektedir (Kırıml1, 2018).

Çatışma örgütün üstesinden gelmesi gereken önemli sorunlardan birisidir (Öztaş ve Akın, 2009) ve çatışmanın yönetilmesi örgüt açısından ayrı bir öneme sahiptir (Demir, 2010). Toplumsal yaşamın bir parçası olan çatışmalar (Karip, 2003) yönetilme durumuna göre işlevsel (yararlı) veya işlevsel olmayan (zararlı) sonuçlar doğurabilir (Topaloğlu, 2010). Çatışmanın etkin bir şekilde yönetilebilmesi için çatışmaya sebep olan kaynakların bilinmesi gerekmektedir. Çatışmaya sebep olabilecek kaynaklar dört ana başlık altında incelenebilir (Kapıcı ve Radmard, 2019);

- Bireylerden Kaynaklanan Sebepler; Kişilik farklılıkları, kaynaklar için rekabet, farklı statü algılamaları ve çıkar farklılıklarıdır.

- Amaçlardan Kaynaklanan Sebepler; Amaç farklılı̆̆ı, güce sahip olma isteği, kıt olan kaynaklara sahip olma isteğidir.

- Yönetimden Kaynaklanan Sebepler; Yöneticilerdeki görüş ve anlayış farklılıkları, görev ve yetki belirsizliği ve önceden yaşanmış ve çözümlenmemiş uyuşmazlıklardır.

- Ö̈rgüt Yapısından Kaynaklanan Sebepler; İletişim eksikliği, hiyerarşi ve faaliyetlerin birbirine bağlılığı olarak incelemek mümkündür.

Çatışma olgusunun içerdiği anlamın değişmesi, çatışmanın kapsam ve sınırlarının genişlemesi ve uluslararası ilişkilerin küreselleşme gibi girdilerle dönüşüm geçirmesi, çatışmaların yönetilmesi konusunda alternatiflerin ortaya çıkmasını sağlamıştır (Akyeşilmen, 2013). Örgütsel çatışma yönetiminde izlenen bazı yöntemler kaçınma, taviz verme, 
uzlaşma, hükmetme, örgütsel önlemler alma ve problem çözme yöntemleridir (Pelit vd., 2013).

Çatışmanın etkin yönetilmesi yararlı yönlerinden en fazla oranda istifade edilip zararlı yönlerinin ise en aza indirilmesiyle mümkündür (Ünlü ve Eroğlu, 2020). Çatışma yaşanmayan bir örgüt üzerine ölü toprağı serpilmiş gibidir. Böyle örgütler iç dinamiklerden yoksun, durağan ve heyecanlarını kaybetmişlerdir (Karip, 2003). Günümüz örgütlerinde çatışma kaçınılmazdır (Sığrı ve Dinçer, 2013). Çünkü örgütü oluşturan birey ya da grupların beklenti, inanış, değer ve tercihlerinin farklı oluşu çatışmayı sürekli bir hale getirmiştir (Arslantaş ve Özkan, 2012).Çatışmanın kaçınılmaz hale gelmesi (Özçel, 2011) yöneticilerin daha çok stres ve çatışma sorunlarıyla baş etmesi anlamına gelmektedir (İmirlioğlu, 2005). Çatışmanın kaçınılmaz olduğu kabul edildiğine göre sonuçlarını örgüt yararına kullanmak ya da olumsuz durumları en aza indirmek için etkin bir çatışma yönetimine ihtiyaç her zaman vardır (Özdemir, 2018).

\section{Araştırma Kavramların İlişkisi ve Hipotezler}

İş stresini etkileyen kaynaklar örgütsel ve bireysel olabilmektedir. Örgüttün neden olduğu stres kaynaklar1; örgüt iklimi, iş yükü, ücret politikası, iletişim sorunları, personel politikası, iş güvensizliği ve vardiyalı çalışmalar iken bireysel stres kaynakları ise kişisel hırslar, işin özellikleri, işin yapısı ve çatışma gibi etkenlerdir (Deveci, 2017). İş stresi, içtimai hayatta birçok probleme sebep olduğu gibi örgütsel hayatta da çatışmaya neden olabilmektedir (Karakulle vd., 2019). Çatışmaların yaşanması ise çalışanlar üzerinde strese sebep olabilmektedir (Kocaman, Kocaman ve Çakır, 2012). Örgütlerde yaşanan stres çatışmanın sebebi olabildiği gibi çatışmalarda stresin müsebbibi olabilmektedirler.

Stresin oluşmasına neden olan birçok etkenin varlığg bu alanda çeşitli çalışmaların yapılmasını sağlamıştır (Örücü ve Demir, 2010). Literatürde stres ve çatışma ile ilgili yapılmış çalışmalardan bazıları ve sonuçları şöyledir; Turunç ve Erkuş (2010), Özafşarlığlu ve Kılıç (2013) ve Tekingündüz vd., (2015)'leri iş-aile çatışmasının iş stresini arttırdığını ve iş tatminini azalttığını tespit etmişlerdir. Gürel (2016), Karabay (2015), Seçilmiş ve Kılıç (2017), Akın ve Karakulak (2019), Ergün ve Yüksel (2019), Sayıldı ve Büyükyılmaz (2020) ve Öztürk ve Türk (2020) ise iş stresinin, iş aile çatışmasını arttırdığı sonucuna varmıştır. Unur ve Pekerşen (2017)'ne göre ise iş stresinin artması çalışanların toksik davranış göstermesine sebep olmaktadır. Savaş ve Erol (2017), çalışanların uzun süreli iş stresine maruz kalması durumunda depresif eğilimler gösterdiğini ve işten ayrılma niyetlerinin arttığı sonucuna varmışlardır. Stres ve çatışma ile ilgili çalışmaların genelde iş-aile çatışması üzerindeki etkisi incelenmiş ve çatışmaların strese sebep olduğu veya stresin çatışmayı doğurduğu sonuçlarına ulaşılmıştır. $\mathrm{Bu}$ çalışmalar 1şı̆̆ında araştırma için oluşturulan hipotezler şu şekildedir;

H1: Çalışanlardaki zaman stresi, görev çatışmasını etkilemektedir.

H3: Çalışanlardaki iş kaygısı, görev çatışmasını etkilemektedir.

H2: Çalışanlardaki zaman stresi, ilişki çatışmasını etkilemektedir.
H4: Çalışanlardaki iş kaygısı, ilişki çatışmasını etkilemektedir.

\section{Yöntem ve Uygulama}

Çalışmanın temel amacı, sivil havacılık sektöründe çalışan iş görenlerin yaşadıkları iş stresinin çatışmaya olan etkisini ortaya koymaktır. Araştırmanın evrenini, Türkiye de faaliyet yürüten işletmelerin sivil havacılık çalışanları oluşturmaktadır. Örneklem seçiminde katmanlı örneklem modeli kullanılmıştır. Bu kapsamda TGS (Turkish Ground Services)'nin İstanbul Hava Limanında çalışan yolcu hizmetleri memuru 460 çalışan, araştırmanın örneklemini oluşturmuştur. Katılımcılara çalışmanın konusu ve gönüllük esası bilgileri verilerek 427 gönüllü ile yüz yüze anket yapılmıştır. Anket yapılırken 7 katılımcının anketi yarıda bırakması ve 4 katılımcının ise cevaplarının tekrar niteliğinde olmasından dolayı 11 anket çalışma dış1 bırakılmıştır. Bu kapsamda oluşturulan araştırma modeli Şekil 1'de verilmiştir.

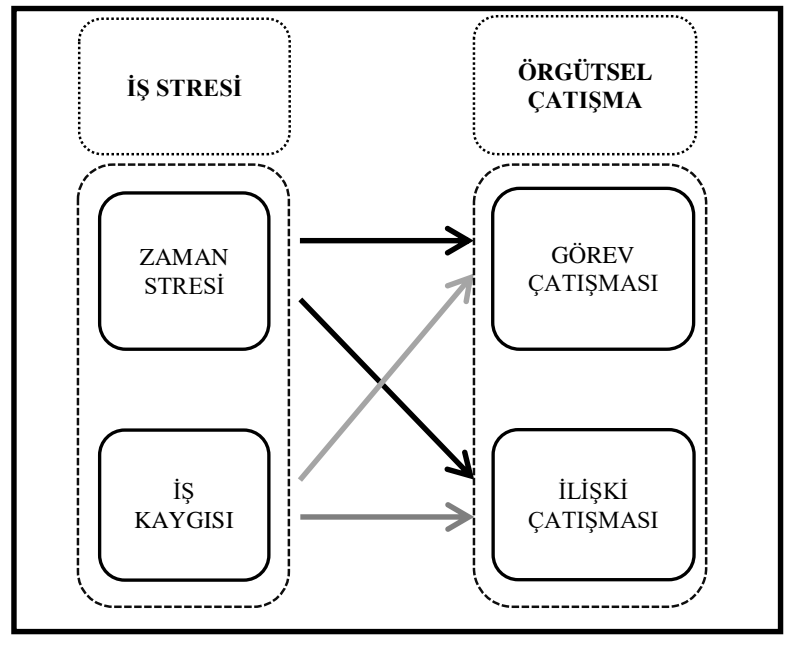

Şekil 1: Araştırma Modeli

Çalışanlar üzerinde yapılan saha araştırması nicel veri toplama tekniği olan anket yöntemi kullanılarak gerçekleştirilmiştir. Elde edilen verilerin istatistiki analizleri için SPSS 25.0 programı kullanılmıştır. Verilerin geçerlilik ve güvenilirlik analizleri, normallik testleri yapılarak hipotezlerin testi için çoklu regresyon analizi yapılmıştır.

\subsection{Demografik Bilgiler}

Tablo 1. Katılımcıların Demografik Bilgileri

\begin{tabular}{llcc}
\hline & & $\begin{array}{c}\text { Sayı } \\
\text { (Kişi) }\end{array}$ & $\begin{array}{c}\text { Yüzde } \\
\%\end{array}$ \\
\hline Cinsiyet & Erkek & 246 & 59,1 \\
\cline { 2 - 4 } & Kadın & 170 & 40,9 \\
\hline Yaş & $15-24$ & 71 & 17,1 \\
\cline { 2 - 4 } & $25-34$ & 203 & 48,8 \\
\cline { 2 - 4 } $35-44$ & 73 & 17,5 \\
\cline { 2 - 4 } & $45-54$ & 34 & 8,2 \\
\cline { 2 - 4 } & $55-64$ & 24 & 5,8 \\
\cline { 2 - 4 } & 65 ve üzeri & 11 & 2,6 \\
\hline
\end{tabular}




\begin{tabular}{llcc}
\hline Eğitim Durumu & İlköğretim & 5 & 1,2 \\
\cline { 2 - 4 } & Lise & 54 & 13,0 \\
\hline Önlisans & 29 & 7,0 \\
\cline { 2 - 3 } & Lisans & 184 & 44,2 \\
\cline { 2 - 3 } Lisansüstü & 144 & 34,6 \\
\cline { 2 - 3 } Toplam & $\mathbf{4 1 6}$ & $\mathbf{1 0 0 , 0}$ \\
\hline
\end{tabular}

Tablo 1'den anlaşılacağı üzere katılımcıların büyük çoğunluğunu erkekler $(\% 59,1)$ oluşturmaktadır. Katılımcılardan en yüksek yaş aralığı \%48,8 ile 25-34 yaş grubudur. Katılımcıların \%44,2'si lisans mezunlarından oluşmaktadır.

\section{2. Ölçüm Araçları}

Çatışma Ölçeği: Giebels ve Janssen (2005) tarafindan geliştirilen, Türkçe uyarlaması Çiçek ve Almalı (2020) tarafından yapılan, görev ve ilişki çatışması adında iki boyuttan ve 8 maddeden oluşan çatışma ölçeği kullanılmıştır. Giebels ve Janssen (2005)'nin araştırmasında cronbach alfa değerleri görev çatışması için $\alpha=0,86$ ve ilişki çatışması için $\alpha=0,90$ olarak ölçülmüştür. Çiçek ve Almalı (2020)'nın çalışmasında ise ölçeğin cronbach $\alpha$ değeri boyutlar için sırasıyla; 0,81 ve 0,73 olarak ölçülmüştür.

İş Stresi Ölçeği: Parker ve DeCotiis (1983) tarafindan geliştirilmiş olan "İş Stresi Ölçeğì" Shukla ve Srivastava (2016) tarafından modifiye edilmiştir. Çiçek (2020) tarafından Türkçeye uyarlanmıştır. Ölçek, 4 maddeden oluşan zaman stresi ve 5 maddeden oluşan iş kaygısı olarak iki boyuttan oluşmaktadır. Parker ve DeCotiis (1983)'in çalışmasında cronbach's alpha değerleri zaman stresi için 0,86 ve iş kaygısı için 0,83 olarak ölçülmüştür. Shukla ve Srivastava (2016)'nın cronbach's alpha değerleri ise sırasıyla 0,86 ve 0,83 olarak aynı bulunmuştur. Çiçek (2020)'nin ise 0,92 ve 0,91 olarak bulunmuştur.

\subsection{Geçerlilik ve Güvenirlilik Analizleri}

Araştırmada kullanılan ölçeklerin yap1 geçerliliği ve güvenirliliğini belirlemek için açımlayıcı faktör analizi yapılmıştır. Faktör analizi öncesi verilerin uygunluğunu tespit edebilmek için KMO ve Bartlett testi yapılmıştır. Çatışma ölçeğine uygulanan test sonucunda $\mathrm{KMO}=, 830$ ve Bartlett testi değeri $\chi 2=1386.130 ; \mathrm{p}=, 000<0,05$ anlaml olarak tespit edilmiştir. Tüm bu değerlerden hareketle çatışma ölçeğine faktör analizi yapılabileceğine karar verilmiş ve faktör analizi sonuçları tablo 2'de verilmiştir.

Tablo 2:Çatışma Ölçeği AFA ve Güvenilirlik Analizleri Sonuçları

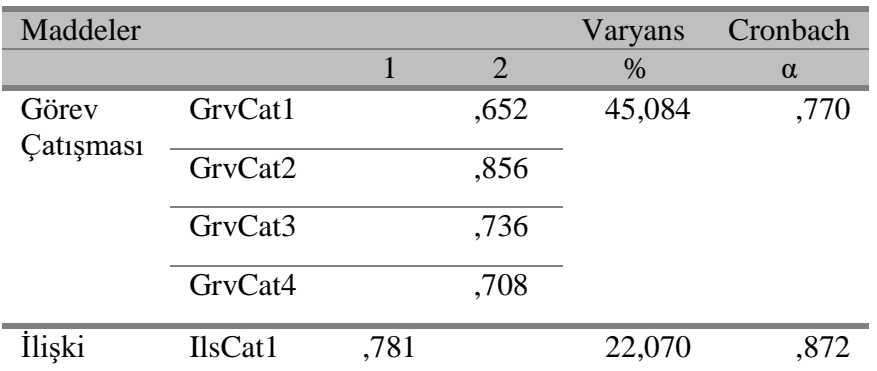

\begin{tabular}{lll} 
Çatışması & IlsCat2 &, 847 \\
\cline { 2 - 3 } & IlsCat3 &, 842 \\
\cline { 2 - 3 } & IlsCat4 &, 810 \\
\hline
\end{tabular}

Toplam Varyans: \%67.154; Tekrarlama Say1s1: 5; Döndürme Yöntemi: Varimax; KMO Uygunluk: 0,830; Bartlett Küresellik Testi: 1.386,007 Anlaml1l1k: $p=, 000$; Goodness of Fit: $\chi 2=28$

Yapılan AFA neticesinde çatışma ölçeği faktör analizi sonuçlarına göre ölçeğinin toplam varyansı açılama yüzdesi \%67,154'tür. Ölçeğin boyutlarının cronbach's alpha değeri ise görev çatışması 0,770 ve ilişki çatışması 0,872 olarak bulunmuştur. $\mathrm{Bu}$ değerler orijinal forma uygun olduğu için çalışmada kullanılan ikinci ölçek olan "İ̧̧ Stresi” ölçeğine KMO ve Bartlett testi uygulanmıştır.

İş stresi ölçeğine uygulanan KMO ve Bartlett testi analiz sonuçlarına göre $\mathrm{KMO}=, 829$ ve Bartlett testi değeri $\chi 2=$ 1.731 .563 ve $p=, 000<0,05$ anlamlı olarak tespit edilmiştir. Bu sonuçlar ölçeğin AFA'ya uygun olduğunun gösterdiğinden ölçeğe AFA uygulanmış ve sonuçlar Tablo 3 'te verilmiştir.

Tablo 3: İş Stresi Ölçeği AFA ve Güvenilirlik Analizleri Sonuçları

\begin{tabular}{|c|c|c|c|c|c|}
\hline \multirow[t]{2}{*}{ Maddeler } & & \multicolumn{3}{|r|}{ Varyans } & \multirow{2}{*}{$\begin{array}{c}\text { Cronbach } \\
\alpha\end{array}$} \\
\hline & & 1 & 2 & $\%$ & \\
\hline \multirow{4}{*}{$\begin{array}{l}\text { Zaman } \\
\text { Stresi }\end{array}$} & ZmnSt1 & &, 580 & 39,584 & ,708 \\
\hline & ZmnSt2 & & 805 & & \\
\hline & $\mathrm{ZmnSt} 3$ & & ,795 & & \\
\hline & $\mathrm{ZmnSt} 4$ & & ,697 & & \\
\hline \multirow[t]{4}{*}{ İş Kaygısı } & IsKay1 & 858 & & 23,965 &, 885 \\
\hline & Iskay2 & 883 & & & \\
\hline & IsKay3 & ,866 & & & \\
\hline & IsKay4 & 827 & & & \\
\hline
\end{tabular}

İş stresi ölçeğinin toplam varyansı açıklama yüzdesi $\% 63,550$ 'dir. Ölçeğin alt boyutları $\alpha$ değeri ise zaman stresi 0,708 ve iş kaygısı 0,885 olarak bulunmuştur.

KMO değerlerinin 0,50'nin üzerinde ve Bartlett küresellik testinin sonuçlarının anlamlı olması gerekmektedir (Tavşancı1, 2010). Ayrıca araştırmada kullanılan tüm maddelerin değerlerinin $\alpha$ değerlerinin 0,70 'in üzerinde olması araştırmanın iç tutarlılığının yüksek olduğunu gösterir (Cronbach, 1951). KMO değerleri çatışma ölçeği için 0,830 , iş stresi ölçeği için 0,829 , Bartlett küresellik testinin sonuçlarının anlamlı ve cronbach's alpha değerlerinin ise 0,70 ve ,88 arasında oluşu ölçeklerimizin geçerlilik ve güvenilirlik adına yeterli düzeyde olduğuna ilişkin kanıt niteliğindedir (Tavşancıl, 2010). Ölçek maddelerinin dağılımının normalliğini tespit etmek için çarpıklık ve basıklık (Swekness - Kurtosis) testleri yapılmış sonuçlar tablo 4 'te verilmiştir. 
Tablo 4: Çarpıklık-Basıklık Değerleri Testi Anlamlılık Düzeyi Sonuçları

\begin{tabular}{|c|c|c|c|}
\hline Ölçek Alt Boyutları & $\mathrm{N}$ & Çarpıklık & Basıklık \\
\hline Görev Çatışması & 416 &,- 415 &,- 212 \\
\hline İlişki Çatışması & & ,772 & ,994 \\
\hline Zaman Stresi & & 134 & 320 \\
\hline İş Kaygısı & & $-1,148$ & ,912 \\
\hline
\end{tabular}

Tablo 4'te görüldüğü üzere çatışma ölçeği değerleri; çarpıklık -,415 ve basıklık 0,994, iş stresi ölçeği değerleri ise çarpıklı $-1,148$ ve basıklık 0,912 olarak tespit edilmiştir. Ölçeklere uygulanan çarpıklık ve basıklık değerleri sonuçlarının değişkenlerin tümü için $\pm 1,5$ aralığında olmasından dolayı, verilerin normal dağılım gösterdiği kabul edilmiştir (Tabachnick vd., 2007).

Ölçeklerimize uyguladığımız AFA sonuçlarına göre ölçeklerin varyansı açıklama yüzdelerinin \% 60’tan yüksek, KMO değerlerinin 0,50 den büyük ve Bartlett Küresellik testi sonuçlarının anlamlı, çarpıklık ve basıklık değerlerinin dağılımın normal olduğunu göstermesinden dolayı, hipotez testleri için regresyon analizi yapılmasına karar verilmiştir.

\section{Bulgular}

İş stresinin görev çatışması ve ilişki çatışmasına etkisini belirleyebilmek için regresyon analizi yapılmıştır. İlk olarak iş stresinin alt boyutları olan zaman stresi ve iş kaygısı boyutlarının, çatışmanın alt boyutu görev çatışmasına olan etkisi araştırılmış ve sonuçlar tablo 5 'te verilmiştir.

Tablo 5: İş Stresi - Görev Çatışması Etki Tablosu

\begin{tabular}{|c|c|c|c|c|c|}
\hline Değişkenler & $\beta$ & $\mathrm{p}$ & $\mathrm{R}^{2}$ & Düz.R ${ }^{2}$ & F \\
\hline Sabit & 1,688 &, 000 & , 139 & ,135 & 33,391 \\
\hline Zaman Stresi &, 138 & ,001 & & & \\
\hline İş Kaygisı & ,374 & ,000 & & & \\
\hline
\end{tabular}

a Bağımlı Değişken: Görev Çatışması; N=416; *p<0,05

Tablo 5'ten anlaşılacağı üzere zaman stresi ve iş kaygısının bağımlı değişken görev çatışmasına etkisini ölçmek için regresyon analizi yapılmıştır. Analiz sonucunda modelin $\mathrm{R}^{2}$ $=, 135$ ile anlaml $(\mathrm{F}(1,415)=33,391 ; \mathrm{p}<, 001)$ olduğu anlaşılmaktadır. Zaman stresinin, görev çatışması $(\beta=, 138$; $\mathrm{p}=001)$ ve iş kaygısına $(\beta=, 374 ; \mathrm{p}<001)$ pozitif yönlü ve anlamlı bir etkisi bulunmuştur. Buradan hareketle $\mathbf{H}_{1}$ ve $\mathbf{H}_{2}$ hipotezleri kabul edilmiştir. $\mathrm{Bu}$ sonuçlar doğrultusunda iş yerinde yaşanan görev çatışmasının \%13'ünün iş stresinden yani zaman stresi ve iş kaygısından kaynaklandığı söylenebilir.

Araştırmamızda ikinci olarak iş stresinin alt boyutları olan zaman stresi ve iş kaygısı boyutlarının, çatışmanın alt boyutu ilişki çatışması üzerine olan etkisi araştırılmış ve sonuçlar tablo 6'da verilmiştir.
Tablo 6: İş Stresi - İlişki Çatışması Etki Tablosu

\begin{tabular}{|c|c|c|c|c|c|}
\hline Değişkenler & $\beta$ & $\mathrm{p}$ & $\mathrm{R}^{2}$ & Düz.R ${ }^{2}$ & $\mathrm{~F}$ \\
\hline Sabit & 2,584 & ,000 &, 174 &, 170 & 43,430 \\
\hline Zaman Stresi & ,025 &, 481 & & & \\
\hline İş Kaygisı & ,386 &, 000 & & & \\
\hline
\end{tabular}

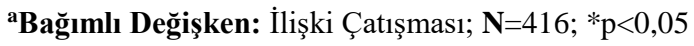

Zaman stresi ve iş kaygısının bağımlı değişken olan ilişki çatışmasına yönelik yapılan regresyon analizi sonucunda modelin $\mathrm{R}^{2}=, 170$ ile anlamlı $(\mathrm{F}(1,415)=43,430 ; \mathrm{p}<, 001)$ olduğu anlaşılmaktadır. Zaman stresinin ilişki çatışmasında $(\beta=, 025 ; p>, 001)$ anlamlı bir etki bulunamamıştır. Bu nedenden ötürü $\mathbf{H}_{3}$ hipotezimiz reddedilmiştir. İş kaygısının ilişki çatışmasında ise $(\beta=, 386 ; p<001)$ pozitif yönlü ve anlamlı bir etki bulunmuştur. Buradan hareketle $\mathbf{H}_{\mathbf{4}}$ hipotezi kabul edilmiştir. Bu sonuçlar doğrultusunda iş yerinde yaşanan görev çatışmasının \%17'sinin iş stresinin alt boyutlarından iş kaygısından kaynaklandığı söylenebilir.

Tablo 7: Çalışma Analiz Sonuçları

\begin{tabular}{llcccc}
\hline \multicolumn{1}{c}{ Yol } & $\boldsymbol{\beta}$ & $\mathbf{p}$ & Hipotez & Sonuç \\
\hline Zaman Stresi & $\rightarrow$ Görv. Çat. &, 138 &, 001 & $\mathrm{H}_{1}$ & Kabul \\
\cline { 2 - 6 } & $\rightarrow$ Görv.Çat. &, 374 &, 000 & $\mathrm{H}_{2}$ & Kabul \\
\hline İsaygıs1 & & & & \\
\hline Zaman Stresi & $\rightarrow$ İlişki Çat. &, 025 &, 481 & $\mathrm{H}_{3}$ & Red \\
\hline İş Kaygıs1 & $\rightarrow$ İlişki Çat. &, 386 &, 000 & $\mathrm{H}_{4}$ & Kabul \\
\hline
\end{tabular}

Tablo 7' den anlaşılacağı üzere, kurduğumuz modelin anlamlı olması neticesinde $\mathbf{H}_{1}, \mathbf{H}_{\mathbf{2}}$ ve $\mathbf{H}_{\mathbf{4}}$ hipotezlerimiz kabul edilmiş ve $\mathbf{H}_{3}$ hipotezimiz ise reddedilmiştir.

\section{Sonuç}

İş yaşamı, insanların hayatının önemli bir kısmını oluşturmaktadır. Yoğun rekabet ortamı, dinamik iş piyasası ve kariyer hesaplarından dolayı çalışanlar strese maruz kalabilmektedirler (Asunakutlu ve Safran, 2006). Stres hemen her insanın maruz kaldığı günümüzün önemli sorunlarından biridir ve çalışma yaşamında birçok stres kaynağı bulunmaktadır (Aktaş, 2001). Çalışanların karşılaştıkları stresi tamamen ortadan kaldırmak mümkün olmadığı için azaltıcı tedbirler alınmalıdır (Şenyiğit, 2004). Çünkü stres, hem çalışanlara, hem de örgüte zarar verebilmektedir (Savaş ve Erol, 2017). Strese maruz kalan iş görenlerinde çatışma yaşaması kaçınılmazdır (Özmutaf, 2007). Örgütsel çatışmaları tamamen ortadan kaldırmak pek mümkün olmadığından örgüt menfaatlerine katkı sağlayacak yönlerine odaklanmak faydalı olabilir. Nitekim çatışmalar örgütlerde yenilikçi paradigmalar ortaya çıkarabilmektedirler (Avc1, 2020).

Çalışmamız neticesinde iş stresinin alt boyutlarından olan zaman stresinin görev çatışmasını pozitif yönde etkilediği sonucuna varılmıştır. Başka bir ifadeyle işinde yeterli zamanının olmadığ 1 baskısını yaşayan iş görenler görevleri ile ilgili mesai arkadaşlarıyla veya üstleriyle uyuşmazlık yaşayabilmektedirler. İşs stresin alt boyutu olan iş kaygısı ise çalışanlarda hem görev çatışmasına, hem de ilişki çatışmasına neden olmaktadır. Yani işten çıkarılma endişesiyle çalışan iş görenler, görev alanlarıyla ilgili çatışma yaşarken arkadaşlarıyla olan ilişkilerinde de 
çatışmalar yaşamaktadırlar. Alan yazınında iş stresinin örgütsel çatışmaya etkisini konu alan çalışmaya rastlanılmamıştır. Fakat çalışmamızla benzer özellik taşıyan araştırmalar olduğundan bu yönde bir kıyaslamaya gidilmiştir. $\mathrm{Bu}$ çalışmalardan bazıları şöyledir; Gürel (2016), iş stresinin iş aile çatışmasını arttırdığını, Onay ve Kılcı (2011), iş stresinin çatışma yaşanması durumunda çalışanların duyarsızlaştığını, Karabay (2015), stresin iş aile çatışmasını arttırdığını, Seçilmiş ve Kılıç (2017) ise benzer şekilde stresin iş aile çatışmasına neden olduğunu, Unur ve Pekerşen (2017), iş stresinin artmasının çalışanların toksik davranış göstermesine sebep olduğunu, Savaş ve Erol (2017), çalışanların uzun süreli iş stresine maruz kalması durumunda depresif eğilimler gösterdiğini tespit etmişlerdir. Literatürdeki araştırmalarla uyumlu olarak ulaştığımız sonuçlar, iş stresinin örgüt içi çatışmayı etkilediğini ortaya koymaktadır.

Örgütlerde stres ve çatışmalar, bazı olumsuz neticeler doğurabilmektedir. $\mathrm{Bu}$ olumsuz sonuçları en az hasarla atlatmak, elbette ki sürecin etkin bir şekilde yönetilebilmesine bağlıdır. İş stresinin, örgüt içi çatışmaya etkisini araştırdığımız çalışmanın neticesinde, yöneticilere matuf önerilerde bulunulabilir.

- İş stresinin, çalışanlar ve örgüt açısından zararlı sonuçlar doğurmaması için belli aralıklarla stres ve çatışma ile ilgili ölçümler yapılıp değerlendirilmeye tabi tutulması faydalı olacaktır.

- Çalışma sonuçlarımız, çalışanların zaman stresi yaşaması durumunda çatışmaya meyilli olduğunu göstermiştir. $\mathrm{Bu}$ sebeple yöneticiler, çalışanların üzerindeki zaman stresini olabildiğince azaltmaya çalışmalıdırlar.

- İş kaygısı olan bireylerin çatışmaya daha yakın olması sonucundan dolayı, yöneticilerin çalışanlarda ki bu kaygının azaltılmasına dönük ve örgütsel bağlılığı arttırıcı tedbirler almaları faydalı olacaktır

Çalışmamız belirli bir zaman aralığında, sivil havacılık sektörü çalışanlarında ve belli bir sayıdaki kişi ile gerçekleştirildiğinden, sonuçların genellenmesi uygun değildir. Faklı sektörler ve farklı bölgelerde benzer çalışmaların yapılması faydalı olacaktır.

\section{Kaynakça}

Adıgüzel, O. (2012). İşle ilgili stres, rol çatışması ve rol belirsizliğinin beklenen personel devri üzerine etkisi: Hemşireler üzerinde bir uygulama. Ulusal Spor Bilimleri Dergisi, 2(2), 129-137

Akçakanat, T. (2019). Hava trafik kontrolörlerinde algılanan iş stresinin işten ayrılma niyeti üzerine etkisinde iş tatmini ve öznel yorgunluk algısının rolü. Süleyman Demirel Üniversitesi İktisadi ve İdari Bilimler Fakültesi Dergisi, 24(4), 901-920. Https://Dergipark.Org.Tr/Tr/Pub/Sduiibfd/706100

Akın, Ö., ve Karakulak, H. (2019). İş-aile ve aile-iş çatışması, iş, aile ve hayat tatmininin işten ayrılma niyeti üzerine etkisi: Karşılıklı ve demografik değişkenli etkileşimler. Uluslararası Ekonomi Ve Yenilik Dergisi, 5(2), 381-403. Https://Doi.Org/10.20979/Ueyd.593488

Akkirman, A. D. (1998). Etkin çatışma yönetimi ve müdahale stratejileri. Dokuz Eylül Üniversitesi I.I.B.F.Dergisi, 13(2), 1-11.

Aktaş, A. M. (2001). Bir kamu kuruluşunun üst düzey yöneticilerinin iş stresi ve kişilik özellikleri. Ankara Üniversitesi Sbf Dergisi, Https://Doi.Org/10.1501/Sbfder_0000001872

Aktekin, E., Özmutaf, N. M., ve Ergani, B. (2018). Kadın yöneticilerin medeni durumlarının iş stresine etkisi: İzmir ilinde bir araştırma. Yönetim Bilimleri Dergisi, 16(32), 577-588.

Https://Dergipark.Org.Tr/Tr/Pub/Comuybd/444535

Arslantaş, H. İ., ve Özkan, M. (2012). İlköğretim okullarında görev yapan öğretmenlerin görüşlerine göre okul müdürlerinin çatışma yönetimi yaklaşımlarının incelenmesi. Kastamonu Eğitim Dergisi, 20(2), 555570.

Asunakutlu, T., ve Safran, B. (2006). Örgütlerde yıldırma uygulamaları (mobbing) ve çatışma arasındaki ilişki. Sosyal Ekonomik Araştırmalar Dergisi, 6(11),110-129. Https://Dergipark.Org.Tr/Tr/Pub/Susead/302835

Avcı, A. (2020). Örgütlerde iç çatışmalar ve yönetimi. AlFarabi International Journal On Social Sciences, 5(2), 6-17. Https://Doi.Org/10.46291/Al-Farabi.050202

Baltacı, A. (2018). Din görevlilerinin iş doyumu, iş stresi, tükenmişlik ve işten ayrılma niyeti arasındaki ilişkiler: Çok örneklemli bir çalışma. Cumhuriyet Ilahiyat Dergisi, 22(3), 1509-1536. Https://Doi.Org/10.18505/Cuid.458233

Bayarçelik, E. B., Durmaz, B. V., ve Gürler, N. (2019). İş stresi ve pozitif psikolojik sermayenin tükenmişlik üzerine etkisi: Bankacılık sektöründe bir araştırma. Insan ve Insan, 6(21), 493-523. Https://Doi.Org/10.29224/İnsanveinsan.513475

Birsel, M., İslamoğlu, G., ve Börü, D. (2009). Kültürel boyutlar içerisinde şekillenen çatışma tarzları. Dokuz Eylül Üniversitesi Işletme Fakültesi Dergisi, 10(2),245262. Https://Dergipark.Org.Tr/En/Pub/İfede/268224

Büyükaslan, H., ve Eriş, H. (2019). Acil servis çalışanlarının iş stresi ve tükenmişlik düzeylerinin iş doyumları üzerine etkisi. Harran Üniversitesi Tlp Fakültesi Dergisi, 16(2), 290-294. Https://Doi.Org/10.35440/Hutfd.560308

Büyükyılmaz, O., Karakulle, İ., ve Karataş, İ. (2018). Örgütsel kariyer yönetiminin duygusal bağl1lık üzerinde etkisinde iş tatmininin aracılık rolü. Çankırı Karatekin Üniversitesi İktisadi ve İdari Bilimler Fakültesi Dergisi, 8(1), 1-29. Https://Doi.Org/10.18074/Ckuiibfd.310160

Cronbach, L. J. (1951). Coefficient alpha and the internal structure of tests. Psychometrik, 16(3), 297-334. Http://Dx.Doi.Org/10.1007/Bf02310555

Çelik, M., ve Turunç, Ö. (2009). Aile-iş çatışması, iş stresi ve örgütsel sadakatin iş performansına etkisi: savunma sektöründe ampirik bir çalışma. Savunma Bilimleri Dergisi, 8(2), 217-245. Https://Doi.Org/10.17134/Sbd.28637 
Çınar, O. (2010). Eğitim ve sağlık alanı çalışanlarının iş stresi düzeyleri. Elektronik Sosyal Bilimler Dergisi,9(33).

Https://Dergipark.Org.Tr/Tr/Pub/Esosder/82527

Çiçek, B. (2020). Hizmetkar liderlik algısının iș stresine etkisi: Sivil havayolu taşımacılığı çalışanları üzerine bir araştırma. Yorum Yönetim Yöntem Uluslararası Yönetim Ekonomi ve Felsefe Dergisi, 8(1),65-78. Https://Doi.Org/10.32705/Yorumyonetim.715709

Çiçek, B., ve Almalı, V. (2020). The effect of toxic leadership on conflict in the workplace. Ekinoks Ekonomi İşletme Ve Siyasal Çalışmalar Dergisi, 7(2), 214-235.

Https://Dergipark.Org.Tr/Tr/Pub/Equinox/777708

Demir, M. (2010). Örgütsel çatışma yönetiminde duygusal zekanın etkisi: Konaklama işletmelerinde işgörenlerin algılamaları üzerine bir araştırma. Doğuş Üniversitesi Dergisi, 11(2), 199-211.

Deveci, B. (2017). İş stresi ve turizm işletmelerinde yapılan araştırmalara ilişkin bir değerlendirme. Mehmet Akif Ersoy Üniversitesi Sosyal Bilimler Enstitüsü Dergisi,9(20),39-53.

Https://Doi.Org/10.20875/Makusobed.306671

Doğan, S., ve Oğuzhan, Y. S. (2020). Algılanan Sosyal desteğin personel güçlendirme ve iş stresine etkisi: Kendilik algısının düzenleyicilik rolü. Ömer Halisdemir Üniversitesi İktisadi ve İdari Bilimler Fakültesi Dergisi, 13(3), 531-545. Https://Doi.Org/10.25287/Ohuiibf.723682

Düşükcan, M. (2018). İş örgütlerinde çatışmaların oluşum kaynakları ve türleri: Büyük ölçekli sanayi işletmelerinde bir uygulama. Selçuk Üniversitesi Sosyal Bilimler Enstitüsü Dergisi. (40), 32-43

Eren, E. (2016). Yönetim ve Organizasyon. İstanbul: Beta Basım Yayım.

Eren, V. (2003). Kamu yönetiminde rekabet, rekabetin kurumsallaştırılması ve rekabet mekanizmaları. Ankara Üniversitesi Sbf Dergisi, 58(4), 83-105.

Ergün, E., ve Yüksel, A. (2019). İș-yaşam çatışmasının çalışanın davranışsal sonuçlarına etkisi ve iş stresinin aracıl1k rolü. Istanbul Aydın Üniversitesi Dergisi,11(1),67-90.

Https://Dergipark.Org.Tr/Tr/Pub/İaud/503584

Ertürk, M. (1993). Organizasyonlarda çatışma, çatışma nedenleri, çatışmanın yönetimi ve Erciyes Üniversitesinde bir anket uygulamas1. Erciyes Üniversitesi Iktisadi Ve İdari Bilimler Fakültesi Dergisi,11,121-147.

Https://Dergipark.Org.Tr/Tr/Pub/Erciyesiibd/447258

Ertürk, M. (2013). Işsletmelerde Yönetim ve Organizasyon. İstanbul: Beta Basım Yayım.

Giebels, E., ve Janssen, O. (2005). Conflict stress and reduced well-being at work: The buffering effect of third-party help. European Journal of Work and Organizational Psychology, 14(2), 137-155. Https://Doi.Org/10.1080/13594320444000236
Göl, E., Arslankılıç, Ç., ve Göl, L. A. (2017). Sağlık kurumlarında yaşanan çatışmaların çözüm yöntemleri. Ekonomi Issletme ve Yönetim Dergisi, 1(2),97-124. Https://Dergipark.Org.Tr/Tr/Pub/Jebm/377474

Güçlü, N. (2001). Stres yönetimi. G. U. Gazi Eğitim Fakültesi Dergisi, 21(1), 91-109.

Gürcüoğlu, S., ve Uyar, M. (2020). Örgütsel çatışma ile örgütsel iklim arasındaki ilişkinin ortaöğretim öğretmenleri perspektifinden incelenmesi. Balıkesir Üniversitesi Sosyal Bilimler Enstitüsü Dergisi,23(43),229-254. Https://Doi.Org/10.31795/Baunsobed.682198

Gürel, E. B. (2016). Duygusal tükenmişlik, iş stresi ve işe bağlılığın iş-aile çatışması üzerindeki etkisi: Amprik bir araştırma. Dumlupınar Üniversitesi Sosyal Bilimler Dergisi,48,349-364.

Https://Dergipark.Org.Tr/Tr/Pub/Dpusbe/283379

Ilo. (2016). Workplace stress: A Collective Challenge. Ilo.

İmirlioğlu, İ. (2005). İş yaşamında çatışma. Verimlilik Dergisi,3,105-125.

Https://Dergipark.Org.Tr/Tr/Pub/Verimlilik/331882

Kapıcı, S., ve Radmard, S. (2019). Eğitim örgütlerinde çatışma ve çatışma yönetimi üzerine bir araştırma: İzmir Balçova örneği. İstanbul Aydın Üniversitesi Ĕ̆itim Fakültesi Dergisi, 2(2), 55-79. Https://Dergipark.Org.Tr/En/Pub/İauefd/587551

Karabay, M. E. (2015). Sağlık personelinin iş stresi, iş- aile çatışması ve iş-aile-hayat tatminlerine yönelik algılarının işten ayrılma niyeti üzerindeki etkilerinin belirlenmesi üzerine bir araştırma. Yönetim Bilimleri Dergisi, 13(26), 113-134. Https://Dergipark.Org.Tr/Tr/Pub/Comuybd/533852

Karakulle, İ., Karademir, Ö., ve Armağan, M. V. (2019). İş stresinin çalışanların kariyer algıları üzerindeki etkisini incelemeye yönelik bir çalışma. International Journal of Management and Administration,3(6),205-224. Https://Doi.Org/10.29064/İjma.557819

Karcıoğlu, F., ve Alioğulları, Z. D. (2012). Çatışmanın nedenleri ve çatışma yönetim tarzları ilişkisi. Atatürk Üniversitesi İktisadi ve İdari Bilimler Dergisi, 26(3-4), 23.

Karip, E. (2003). Eğitimsel liderlik. Ankara: Pegem Yayıncılık.

Kaya, İ. (2010). Konaklama işletmeciliğinde stratejik yönetim süreci: Kavramsal bir yaklaşım. KMÜ Sosyal ve Ekonomik Araştırmalar Dergisi.12(18), 27-35

Kaya, M. D., Güzel, D., ve Çubukçu, B. (2011). Ilıca şeker fabrikası çalışanlarının iş memnuniyeti, ergonomik çalışma koşulları ve iş stresi yönünden incelenmesi. Atatürk Üniversitesi İktisadi ve İdari Bilimler Dergisi, 25(2), 51-60. Https://Dergipark.Org.Tr/Tr/Pub/Atauniiibd/35641

Kaynak, İ. (2020). Örgüt kültürünün kurumsal imaja etkisi. Bitlis Eren Üniversitesi İktisadi ve İdari Bilimler Fakültesi Akademik İzdüşüm Dergisi, 5(2), 136-148. 
Kırımlı, Y. (2018). Örgütsel çatışma çözümü tekniklerinde güncel bir yaklaşım: Psikodrama. İş'te davranış Dergisi, 3(2), 148-161. Https://Doi.Org/10.25203/İdd.420651

Kocaman, S., Kocaman, S., ve Çakır, N. (2012). Konaklama işletmelerinde örgüt kültürünün örgütsel çatışma üzerine etkileri: Alanya bölgesinde bir araştırma. Muğla Üniversitesi Sosyal Bilimler Enstitüsü Dergisi, 28, 17-34

Koçel, T. (2014). İşletme Yöneticiliği. İstanbul: Beta Basım Yayım.

Köse, E. (2020). Duygusal emek davranışı ile tükenmişlik algısı arasındaki ilişkide iş stresinin aracılık etkisi: Bankacılık sektöründe bir araştırma. Aksaray Üniversitesi İktisadi ve İdari Bilimler FakültesiDergisi,12(3),39-50. Https://Dergipark.Org.Tr/Tr/Pub/Aksarayiibd/748917

Onay, M., ve Kılc1, S. (2011). İş stresi ve tükenmişlik duygusunun işten ayrılma niyeti üzerine etkileri: Garsonlar ve aşçıbaşılar. Organizasyon ve Yönetim Bilimleri Dergisi, 3(2), 363-372. Https://Dergipark.Org.Tr/Tr/Pub/Oybd/171076

Örücü, E., ve Demir, B. (2010). Banka çalışanlarında iş stresi ve Muğla ili örneği. Atatürk Üniversitesi İktisadi ve Idari Bilimler Dergisi, 13(1). Https://Dergipark.Org.Tr/Tr/Pub/Atauniiibd/35147

Özafşarlıŏlu, S., ve Kılıç, R. (2013). Örgütlerde stres kaynaklarının çalışanların iş-aile çatışması üzerine etkisi. Uşak Üniversitesi Sosyal Bilimler Dergisi, 6(3), 208-237. Https://Doi.Org/10.12780/Uusbd249

Özalp, İ. (1989). Örgütlerde çatışma. Anadolu Üniversitesi Íktisadi ve İdari Bilimler Fakültesi Dergisi, 7(1), 81114. Https://Dergipark.Org.Tr/Tr/Pub/Anadoluibfd/631755

Özçel, S. (2011). Çatışma önleme teorisi ve pratiği: Makedonya ve birleşmiş milletler barış gücü (Unpredep) örnek olayı. Çankırı Karatekin Üniversitesi İktisadi ve İdari Bilimler Fakültesi Dergisi, 1(1), 41-65.

Özdemir, N. (2018). Okullarda öğretmenlerin yaşadığı çatışma ve çatışma yönetim stilleri. Cumhuriyet Üniversitesi Edebiyat Fakültesi Sosyal Bilimler Dergisi,42(2),93-116.

Https://Dergipark.Org.Tr/En/Pub/Cumusosbil/495677

Özmutaf, M., ve Mizrahi, R. (2017). Smmm ve diğer muhasebe çalışanları kapsamında, iş stresinin iş performansına etkisi: İzmir ilinde bir araştırma. Süleyman Demirel Üniversitesi Vizyoner Dergisi, 8(18),1-12. Https://Doi.Org/10.21076/Vizyoner.292507

Özmutaf, N. M. (2007). Örgütlerde bireysel performans unsurları ve çatışma. C. $\ddot{U}$. İktisadi ve İdari Bilimler Dergisi. 8(2), 41-59.

Öztaş, U., ve Akın, O. (2009). Örgütsel çatışma yönetiminde cinsiyet farkl1lıkları: Antalya serbest bölgesinde bir araştırma. Organizasyon ve Yönetim Bilimleri Dergisi, 1(1), 9-24. Https://Dergipark.Org.Tr/En/Pub/Oybd/170998
Öztürk, M., ve Türk, A. (2020). Sosyomografik değişkenler ve iş-aile yaşam çatışmasının algılanan iş stresi üzerindeki etkisi: Sosyal hizmet kuruluşları örneği. Cumhuriyet Üniversitesi Edebiyat Fakültesi Sosyal Bilimler Dergisi,44(1),187-202. Https://Dergipark.Org.Tr/Tr/Pub/Cumusosbil/729905

Parker, D. F., ve Decotiis, T. A. (1983). Organizational determinants of job stress. Organizational Behavior and Human Performance, 32(2), 160177.Https://Doi.Org/10.1016/0030-5073(83)90145-9

Pelit, E., Keleş, Y., ve Kılıç, İ. (2013). Otel işletmeleri yöneticilerinin kişilik özellikleri ile çatışma yönetme yöntemleri arasındaki ilişki. Elektronik Mesleki Gelişim ve Araştırmalar Dergisi, 1(1), 3-19.

Sarpkaya, R. (2002). Egitim örgütlerinde çatışma yönetimi ve bir örnek olay. Kuram ve Uygulamada Ĕ̆itim Yönetimi, 31(31), 414-429.

Savaş, A. C., ve Erol, F. (2017). Eğitim personellerinde iş stresinin işten ayrılma niyetine etkisinde depresyon düzeylerinin aracılık etkisi. Yaşam Becerileri Psikoloji Dergisi, $1(2)$,

115-123.

Https://Doi.Org/10.31461/Ybpd.354488

Sayıldı, H., ve Büyükyılmaz, O. (2020). İş-aile çatışması, aile-iş çatışması ve iş stresi arasındaki ilişki: Üniversite personeli üzerine bir araştırma. Economics Business and Organization Research, 2(1),52-69. Https://Dergipark.Org.Tr/Tr/Pub/Ebor/707538

Seçilmiş, C., ve Kılıç, İ. (2017). Örgütsel güven, iş-aile yaşam çatışması ve işten ayrılma niyeti ilişkisinin belirlenmesi: Seyahat acentelerinde bir uygulama. Turizm Akademik Dergisi, 1(4), 65-79

Shukla, A., ve Srivastava, R. (2016). Development of short questionnaire to measure an extended set of role expectation conflict, coworker support and work-life balance: The New Job Stress Scale. Cogent Business and Management, 3(1). Https://Doi.Org/10.1080/23311975.2015.1134034

Sığrı, Ü., ve Dinçer, A. P. (2013). İşletmelerdeki istihdam biçimleri ve liderlik tarzlarının çatışma yönetimi tarzlarıyla uyumlandırılmasına yönelik öneriler. Uluslararası Yönetim İktisat ve Işletme Dergisi,9(18),195-213. Https://Doi.Org/10.11122/Ijmeb.2013.9.18.430

Sökmen, A., ve Yazıcığlu, İ. (2005). Thomas modeli kapsamında yöneticilerin çatışma yönetimi stilleri ve tekstil işletmelerinde bir alan araştırması. Gazi Üniversitesi Ticaret ve Turizm Eğitim Fakültesi Dergisi,1,1-19.

Https://Dergipark.Org.Tr/En/Pub/Gaziticaretturizm/639 606

Şahin, F. N., ve Çekmecelioğlu, H. G. (2016). Çatışma yönetim stratejilerinin iş performansı üzerine etkileri: Güvenlik sektörü üzerine bir araştırma. Kocaeli Üniversitesi Sosyal Bilimler Dergisi, 32, 167-188. Https://Dergipark.Org.Tr/En/Pub/Kosbed/524858

Şenyiğit, G. (2004). Çalışma hayatında stres. Verimlilik Dergisi,(3),103-120.

Https://Dergipark.Org.Tr/Tr/Pub/Verimlilik/332161 
Tabachnick, B. G., Fidell, L. S., ve Ullman, J. B. (2007). Using multivariate statistics. New York: Pearson.

Tavşancıl, E. (2010). Tutumların ölçülmesi ve spss ile veri analizi. İstanbul: Nobel Yayın Dağıtım.

Tekingündüz, S., Kurtuldu, A., ve Öksüz, S. (2015). İş-aile yaşam çatışması, iş tatmini ve iş stresi arasındaki ilişkiler. Siyaset Ekonomi ve Yönetim AraştırmalarıDergisi,3(4),27-42.

Https://Dergipark.Org.Tr/Tr/Pub/Seyad/709720

Tokat, B. (1999). Örgütlerde çatışma ve çatışmanın yönetimi. Dumlıpınar Üniversitesi Sosyal Bilimler Dergisi, 1, 23-40

Topaloğlu, C. (2010). Örgüt içi çatışmaların yönetim süreci: Otel işletmeleri açısından kuramsal bir değerlendirme. Sosyal Ekonomik Araştırmalar Dergisi,10(20),97-114.

Https://Dergipark.Org.Tr/Tr/Pub/Susead/302461

Topaloğlu, C., ve Boylu, Y. (2006). Örgüt içi çatışmaların türleri: Otel işletmeleri açısından ayrıntılı bir inceleme. Muğla Üniversitesi Sosyal Bilimler EnstitüsüDergisi, 16,1-27 Https://Dergipark.Org.Tr/En/Pub/Musbed/250636

Torun, N., ve Tekin, P. Ş. (2014). Ankara ilinde çalışan sağlık kurumları yöneticilerinin iş stresi ve kişilik özellikleri açısından değerlendirilmesi. Ankara Să̆llk Hizmetleri Dergisi, 13(1), 45-56. Https://Doi.Org/10.1501/Ashd_0000000097

Turunç, Ö., ve Çelik, M. (2010). Çalışanların algıladıkları örgütsel destek ve iş stresinin örgütsel özdeşleşme ve iş performansina etkisi. Yönetim ve Ekonomi: Celal Bayar Üniversitesi İktisadi ve İdari Bilimler Fakültesi Dergisi, 17(2),

Https://Dergipark.Org.Tr/Tr/Pub/Yonveek/165728

Turunç, Ö., ve Erkuş, A. (2010). İş-aile yaşam çatışmasının iş tatmini ve örgütsel bağlllık üzerine etkileri: İş stresinin aracılık rolü. Sosyal Ekonomik Araştırmalar
Dergisi,

10(19),

415-440. Https://Dergipark.Org.Tr/Tr/Pub/Susead/302522

Uludağ, G. (2019). İş stresi ve motivasyon ilişkisine yönelik bir alan araştırması. Adıyaman Üniversitesi Sosyal Bilimler Enstitüsü Dergisi, 33, 411-439. Https://Doi.Org/10.14520/Adyusbd.605567

Unur, K., ve Pekerşen, Y. (2017). İş stresi ile toksik davranışlar arasındaki ilişki: Aşçılar üzerinde bir araştırma. Seyahat ve Otel Işsletmeciliği Dergisi, 14(1),108-129. Https://Doi.Org/10.24010/Soid.303722

Ünlü, F. S., ve Eroğlu, D. T. (2020). Çatışma eylem stilleri. Kurgu,28(1), $122-140$ Https://Dergipark.Org.Tr/En/Pub/Kurgu/720078

Yaşartürk, F., ve Yılmaz, H. (2019). Rekreatif etkinliklere katılan kamu personellerinin iş stresi ve serbest zamanda algılanan özgürlük düzeyleri arasındaki ilişkinin incelenmesi. Manas Sosyal Araştırmalar Dergisi, 8(1), 1325-1335. Https://Doi.Org/10.33206/Mjss.499731

Yelkikalan, N. (2006). Aile şirketlerinde çatışma ve bir çözüm önerisi: Stratejik planlama. Kocaeli Üniversitesi Sosyal Bilimler Enstitüsü Dergisi, 2(12), 195-209.

Yetim, E., ve Çevik, D. D. (2019). Bir iş sağlığı konusu olarak öğretmenlerde iş stresi ve başa çıkma yolları: Alan araştırması. Journal Of Awareness, 3(5),637-652. Https://Doi.Org/10.26809/Joa.2018548676

Yıldız, S., ve Bayrakçı, C. (2020). İşyeri nezaketsizliği ile iş stresi arasındaki ilişki: Akademisyenler üzerine bir araştırma. Pamukkale Üniversitesi Sosyal Bilimler Enstitüsü Dergisi, 40, 515-529. Https://Dergipark.Org.Tr/Tr/Pub/Pausbed/646525

Yıldız, T., ve Şimşek, Y. (2020). Sivil havacılık işletmelerinde çalışanların yaşam doyumunun, iş stresi ve işten ayrılma niyetine etkisinin belirlenmesi: Kars Harakani Hava Limanı örneği. Çalışma İlişkileri Dergisi, 11(2), 59-76. Https://Dergipark.Org.Tr/Tr/Pub/Cider/768956 


\section{Extended Abstract}

\section{Introduction}

Employees spend a significant amount of time in their organizations. Employees who cannot be deprived of emotions and behavior may encounter some negative situations arising from work or their friends during this period. Conflict conflict arising with stress-like factors encountered in business life has some positive aspects. However, together with the positive aspects of conflict, it can also cause negative situations in organizations.

\section{Purpose}

The aim of this study is to reveal the effect of stress experienced in organizations on intra-organizational conflicts and in this context the following hypotheses have been created.

$\boldsymbol{H}_{1}$ : Time stress in employees affects task conflict.

$\boldsymbol{H}_{2}$ : Work anxiety in employees affects task conflict.

$\boldsymbol{H}_{3}$ : Time stress in employees affects relationship conflict.

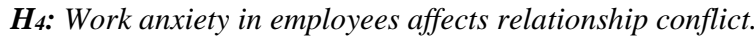

\section{Conceptual/Theoretical Framework}

Stress, which has psychological effects on people and affects behaviors, relationships and productivity in daily life (Y1ldiz \& Bayrakç1, 2020), is not a health problem but the first sign of a harmful physical and emotional situation (ILO, 2016). Perceived stress as an abstract concept is an issue that needs to be dealt with due to its possible negativities (Ergün \& Yüksel, 2019). It can occur in all areas of life, sometimes add strength to the individual and sometimes prevent what they can do (Yetim \& Çevik, 2019), affecting not only mental and physical health but also working performance (Yaşartürk \& Yılmaz, 2019), It is a concept that increases performance up to a certain level and decreases performance after that level (Çelik \& Turunç, 2009). The stress experienced by every individual in the society for various reasons creates negative effects on both herself and her environment (Kaya, 2010). In this context, it is not only a problem affecting the employees (Çelik \& Turunç, 2009), but also an issue that causes some economic difficulties for organizations (Bayarçelik et al., 2019).

Organizations that make up an important part of social life have different people and groups within their structures (İmirlioğlu, 2005). The conflict of those who are in this interaction in organizations is a reality of organizational life (Karcioğlu \& Alioğulları, 2012). Organizational conflicts; It is a process that is affected by the qualifications and relationships of the parties, the issue and social environment that caused the conflict, the tactics and strategy applied during the conflict, and its consequences (Sökmen and Yazıcıŏglu, 2005).

\section{Method}

The main purpose of the study is to reveal the effect of the work stress experienced by employees working in the civil aviation sector on the conflict. The universe of the research is civil aviation workers. The field research conducted on employees was carried out using the survey technique, which is one of the quantitative research methods. Within this scope, a survey was conducted with the passenger services officers employed at Istanbul Airport. A data set was created with the answers received from 416 people and the data were analyzed in the SPSS 25.0 program. The measurement tools used in the research are:

Conflict Scale: The conflict scale, which was developed by Giebels and Janssen (2005) and whose Turkish adaptation was made by Çiçek and Almalı (2020), called task and relationship conflict, consisted of two dimensions and 8 items. Cronbach alpha values in the study of Giebels and Janssen (2005) are task conflict $\alpha=0.86$ and relationship conflict $\alpha=0.90$. Cronbach $\alpha$ value of the scale in the study of Çiçek and Almalı (2020) respectively; It has been measured as 0.81 and 0.73 .
Work Stress Scale: It was developed by Parker and DeCotiis (1983) and modified by Shukla and Srivastava (2016). The scale consists of two dimensions: time stress consisting of 4 items and work anxiety consisting of 5 items. In the study of Parker and DeCotiis (1983), Cronbach's alpha values were measured as 0.86 for time stress and 0.83 for work anxiety. Cronbach's alpha values of Shukla and Srivastava (2016) were found to be the same as 0.86 and 0.83 , respectively.

\section{Findings and Discussion}

Within the scope of the research, regression analysis was conducted to determine the effect of job stress on task conflict and relationship conflict. First of all, the effects of time stress and work anxiety, sub-dimensions of work stress, on task conflict, the sub-dimension of conflict, were investigated.

Regression analysis was conducted to measure the effect of time stress and work anxiety on the dependent variable task conflict. As a result of the analysis, it is understood that the model is significant with $\mathrm{R}^{2}=.135(\mathrm{~F}(1,415)=33,391 ; \mathrm{p}<, 001)$. Time stress had a positive and significant effect on task conflict $(\beta=$, $138 ; p=001)$ and work anxiety $(\beta=, 374 ; p<001)$. Hence, $H_{1}$ and $\mathrm{H}_{2}$ hypotheses were accepted.

Secondly, in our study, the effects of time stress and work anxiety, which are sub-dimensions of work stress, on relationship conflict, the sub-dimension of conflict, were investigated.

As a result of the regression analysis of the relationship conflict, which is the dependent variable of time stress and work anxiety, it is understood that the model is significant with $\mathrm{R}^{2}=.170(\mathrm{~F}$ $(1,415)=43,430 ; p<, 001)$. There was no significant effect of time stress on relationship conflict $(\beta=.025 ; p>, 001)$. For this reason, our $\mathrm{H}_{3}$ hypothesis was rejected. A positive and significant effect was found in the relationship conflict of work anxiety $(\beta=$, 386; $\mathrm{p}<001)$. Hence, the $\mathrm{H}_{4}$ hypothesis was accepted.

\section{Result and Recommendations}

As a result of our study, it was concluded that time stress, which is one of the sub-dimensions of work stress, positively affects task conflict. In other words, employees who are under pressure of not having enough time in their job experience disagreement with their colleagues or superiors regarding their duties. Work anxiety, which is the sub-dimension of work stress, causes both task conflict and relationship conflict in employees. In other words, employees who work with the concern of their dismissal experience conflicts in their relations with their friends while experiencing conflicts about their fields of duty. The results we obtained as a result of this study revealed that stress affects conflict, in accordance with the literature.

Stress and conflicts in organizations can have some negative consequences. Avoiding these results with the least damage depends on the effective management of the process. As a result of the study we investigated the effect of work stress on organizational conflict, suggestions can be made to managers.

- In order to prevent work stress from causing harmful consequences for employees and the organization, it will be beneficial to take measurements and evaluate stress and conflict at regular intervals.

- Our study results showed that employees are prone to conflict when they experience time stress. For this reason, managers should try to reduce the time stress on employees as much as possible.

- Since individuals with work anxiety are closer to conflict, it will be beneficial for managers to take measures to reduce this anxiety in employees and to increase organizational commitment. 
EK-1: Etik Kurul Onayı

Evrak Tarih ve Sayısı: 25.11.2020-E.13692

T.C.

MUŞ ALPARSLAN ÜNIVERSITESI

BİLİMSEL ARAŞTIRMA VE YAYIN ETİĞİ KURULU

\begin{tabular}{|c|c|c|}
\hline Toplantı Tarihi: 25.11 .2020 & Toplantı Sayısı: 13 & Karar Sayısı: 22 \\
\hline \multicolumn{3}{|c|}{$\begin{array}{l}\text { Bilimsel Araştırma ve Yayın Etiği Kurulu, Kurul Başkanı Prof. Dr. Cevad SELAM başkanlığında } \\
\text { toplanarak aşağıdaki kararları almıştır. } \\
\text { KARAR-5: Malazgirt Meslek Yüksekokulu Müdürlüğünün 09.11.2020 tarihli ve E.13066 sayılı yazısı } \\
\text { okundu ve ekleri incelendi. } \\
\text { Yapılan incelemeler sonucunda; Üniversitemiz Malazgirt Meslek Yüksekokulu Finans Bankacılık ve } \\
\text { Sigortacılık Bölümünde görev yapan Öğr. Gör. İnan KAYNAK’ın sorumlu araştırmacısı olduğu “Sivil Hayvancılık } \\
\text { Çalışmalarındaki İş Stresinin Örgüt İçi Çatış̧maya Etkisi” isimli araştırması Bilimsel Araştırma ve Yayın Etiği } \\
\text { Kurulu tarafından uygun görülmüş olup, durumun Malazgirt Meslek Yüksekokulu Müdürlüğüne bildirilmesine, }\end{array}$} \\
\hline \multicolumn{3}{|l|}{ Oy birliği ile karar verildi. } \\
\hline \multicolumn{3}{|c|}{$\begin{array}{c}\text { BAŞKAN } \\
\text { (e-imzalıdır) } \\
\text { Prof. Dr. Cevad SELAM } \\
\text { Kurul Başkanı }\end{array}$} \\
\hline ÜYE & $\ddot{\mathbf{U Y E}}$ & $\ddot{\mathbf{U} Y E}$ \\
\hline $\begin{array}{c}\text { (e-imzalıdır) } \\
\text { Prof. Dr. Harun POLAT } \\
\text { Fen Edebiyat Fakültesi Öğr. } \\
\text { Üyyesi }\end{array}$ & $\begin{array}{c}\text { (e-imzalıdır) } \\
\text { Doç. Dr. Hanifí KÖRKOCA } \\
\text { SBF Öğr. Üyesi }\end{array}$ & $\begin{array}{l}\text { (e-imzalıdır) } \\
\text { Doç. Dr. Bünyamin } \\
\text { SARIKAYA } \\
\text { Eğitim Fakültesi Öğr. Üyesi }\end{array}$ \\
\hline $\begin{array}{c}\text { ÜYE } \\
\text { (e-imzalıdır) } \\
\text { Doç. Dr. Sedat KARDAŞ } \\
\text { Fen Edebiyat Fakültesi Öğr. } \\
\text { Üyesi } \\
\end{array}$ & $\begin{array}{c}\text { ÜYE } \\
\text { (e-imzalıdır) } \\
\text { Doç. Dr. Mehmet } \\
\text { SALMAZZEM } \\
\text { İslami İlimler Fakültesi Öğr. } \\
\text { Üyesi } \\
\end{array}$ & $\begin{array}{c}\text { ÜYE } \\
\text { (e-imzalıdır) } \\
\text { Dr. Öğr. Üyesi Demet } \\
\text { DENİZ } \\
\text { YILMAZ } \\
\text { Ĕğitim Fakültesi Öğr. Üyesi }\end{array}$ \\
\hline $\begin{array}{c}\text { ÜYE } \\
\text { (e-imzalıdır) } \\
\text { Dr. Öğr. Üyesi Recep } \\
\text { YILMAZ IIF Öğr. Üyesi }\end{array}$ & $\begin{array}{c}\text { ÜYE } \\
\text { (e-imzalıdır) } \\
\text { Dr. Öğr. Üyesi Hasan } \\
\text { TASALI SBF Öğr. Üyesi }\end{array}$ & \\
\hline
\end{tabular}

